\title{
Pengaruh Manajemen Peserta Didik Terhadap Prestasi Belajar Peserta Didik Madrasah Aliyah Negeri 1 Banyuwangi
}

\author{
Mamlukhah $^{1}$, Amirotun Nahdliyah ${ }^{2}$, Hanim Wafiroh $^{3}$ \\ e-mail: mamlukhah@iaida.ac.id ${ }^{1,}$ amirohnahdliyah@gmail.com ${ }^{2}$, \\ hanim.wafiroh@gmail.com ${ }^{3}$ \\ Prodi Manajemen Pendidikan Islam \\ Institut Agama Islam Darussalam Blokagung Banyuwangi
}

\begin{abstract}
This research is directed at 4 main points, namely a. To find out the application of the management of students of Madrasah Aliyah Negeri 1 Banyuwangi in the academic year2018 / 2019.b. To find out the learning achievement of students of Madrasah Aliyah Negeri 1 Banyuwangi in the academic year of 2018 / 2019. c. To find out the effect of student management on the learning achievement of students of Madrasah Aliyah Negeri 1 Banyuwangi 2018/2019 academic year. $d$. To find out how much influence the management of students on the learning achievement of students of Banyuwangi State Islamic Senior High School 1 in 2018/2019. This research uses quantitative descriptive method with the technique of produc moment in the validity test and to find the reliability of the data using the alpha formula, while in the hypothesis test using the f test and t test then for the technique of data analysis using the normality test using the regression model. The population of this study is the 33 Madrasah Aliyah Negeri 1 Banyuwangi teacher's council. To measure the researchers' variable, the questionnaire was used to vary teaching methods of learning motivation. After analyzing the data collected, it was found that (1) the management of Madrasah Aliyah Negeri 1 Banyuwangi students was classified as good (2) the learning achievement of Madrasah Aliyah Negeri 1 Banyuwangi students was very good (3) there was an influence on the management of Madrasah students in Madrasah students Banyuwangi Aliyah Negeri 1 2018/2019 academic year is 95.4\%. Key words: Student Management, Learning Achievement
\end{abstract}

Key words: Student Management, Learning Achievement

\begin{abstract}
Abstrak
Penelitian ini diarahkan pada 4 hal pokok, yaitu a. Untuk mengetahui penerapan manajemen peserta didik Madrasah Aliyah Negeri 1 Banyuwangi tahun pembelajaran2018/2019.b. Untuk mengetahui prestasi belajar peserta didik Madrasah Aliyah Negeri 1 Banyuwangi tahun pembelajaran2018/2019. c. Untuk mngetahui pengaruh manajemen peserta didik terhadap prestasi belajar peserta didik Madrasah Aliyah Negeri 1 Banyuwangi tahun pembelajaran 2018/2019. d. Untuk mngetahui seberapa besar pengaruh manajemen peserta didik terhadap prestasi belajar peserta didik Madrasah Aliyah Negeri 1 Banyuwangi tahun pembelajaran 2018/2019. Penelitian ini menggunakan metode deskriptif kuantitatif dengan Teknik produc moment dalam uji faliditas dan untuk mencari reabilitas data menggunakan rumus alpha, sedangkan pada uji hipotesis menggunakan uji $f$ dan uji $t$ kemudian untuk Teknik analisis data menggunakan uji normalitas dengan menggunakan model regresi. Populasi penelitian ini adalah dewan guru Madrasah Aliyah Negeri 1 Banyuwangi berjumlah 33. Untuk mengukur variable peneliti menggunakan kuesioner untuk variasi metode mengajar motivasi belajar. Setelah melakukan analisis data yang dikumpulkan, ditemukan bahwa (1) manajemen peserta didik Madrasah Aliyah Negeri 1 Banyuwangi tergolong baik (2) prestasi belajar peserta didik Madrasah Aliyah Negeri 1 Banyuwangi sangat baik (3) ada pengaruh manajemen peserta didik terhadap prestasi belajar peserta didik Madrasah Aliyah Negeri 1 Banyuwangi tahun pembeljaran 2018/2019 adalah sebesar 95,4\%.
\end{abstract}

Kata-kata kunci: Manajemen Peserta Didik, Prestasi Belajar

Pengaruh Manajemen Peserta Didik Terhadap Prestasi Belajar Peserta Didik

Madrasah Aliyah Negeri 1 Banyuwangi

Mamlukhah, Amirotun Nahdliyah, Hanim Wafiroh 


\section{A. Pendahuluan}

1. Latar Belakang

Manajemen bertujuan untuk melaksanakan gagasan kegiatan administrasi, agar berjalan sesuai dengan pola dan rencana yang dibuat bersama. Manajemen tidak akan berhasil apabila yang menjalankan tersebut hanya kepala madrasah tanpa didukung oleh aparatur sekolah yang ada dibawahnya. Wakil kepala madrasah bagian dari urusan kurikulum, administrasi keuangan, sarana prasarana, serta kesiswaan dan hubungan masyarakat. Manajemen peserta didik merupakan bagian penting yang harus di perhatikan dalam upaya mencapai tujuan pendidikan di sekolah. Program-program kegiatan manajemen peserta didik yang di selenggarakan harus didasarkan kepada kepentingan, perkembangan dan peningkatan kemampuan peserta didik dalam bidang kognitif, psikomotorik, afektif dan sesuai dengan keinginan bakat dan minat peserta didik. Pengadaan program kegiatan manajemen peserta didik diharapkan dapat menghasilkan keluaran yang bermutu. Hal ini sesuai dengan pendapat Prihatin (2014:9) mengatakan "Manajemen peserta didik adalah suatu kegiatan-kegiatan yang menunjang proses belajar mengajar disekolah sehingga dapat memberikan kontribusi bagi pencapaian tujuan sekolah dan tujuan pendidikan secara keseluruhan".

Menurut Nasihin dan Sururi (2008:205) mengatakan "manajemen peserta didik adalah layanan yang memusatkan perhatian pada pengaturan, pengawasan, dan layanan peserta didik di kelas dan di luar kelas seperti: pengenalan, pendaftaran, layanan individuan, mulai pengembngan keseluruhan kemampuan, minat, kebutuhan sampai peserta didik matang sekolah". Dari pengertian diatas dapat ditarik kesimpulan manajemen peserta didik merupakan suatu penataan atau pengaturan segala aktivitas yang berkaitan dengan peserta didik, yaitu mulai masuknya peserta didik sampai dengan keluarnya peserta didik dari suatu lembaga. Tujuan pendidikan agar bisa tercapai, salah satu usahanya yaitu dengan adanya manajemen peserta didik. 
Dalam pembinaan peserta didik program dan kegiatan yang berlangsung melibatkan peserta didik dalam sasaranya. Sasaran akhir dari pembinaan peserta didik adalah perkembangan peserta didik yang optimal sesuai dengan karakteristik pribadi, tugas perkembangan, kebutuhan, bakat, minat dan kreativitas peserta didik itu sendiri. Madrasah Aliyah Negeri 1 Banyuwangi mengalami peningkatan peserta didik dalam setiap tahunnya akan tetapi MAN 1 Banyuwangi juga semakin gemilang mengukir prestasi baik dibidang akademik maupun non akademik diantaranya: juara 2 lomba futsal tingkat wilayah kabupaten/kota tahun 2018, juara syarhil Al Quran se_kabupaten Banyuwangi, English olimpiade juara 1 tingkat kabupaten 2019, lomba baca berita juara 3 tingkat kabupaten 2019 dan masih banyak lagi, oleh karena itu peneliti tertarik melakukan penelitian di Madrasah Aliyah Negeri 1 Banyuwangi.

Berdasarkan observasi awal, sesuai informasi yang disampaikan langsung oleh kepala Madrasah Aliyah Negeri 1 Banyuwangi pada tanggal 18 Oktober bahwasannya pelaksanaan manajemen peserta didik di Madrasah Aliyah Negeri 1 Banyuwangi sudah dilaksanakan sebagaimana mestinya sesuai dengan prinsip dasar manajemen peserta didik. Manajemen peserta didik di Madrasah Aliyah Negeri 1 Banyuwangi bertujuan untuk membantu peserta didik mengembangkan diri. Upaya itu menjadi sempurna karena peserta didik sendiri secara aktif berupaya mengembangkan dirinya sesuai dengan program-program yang dilakukan sekolah. Oleh karena itu diperlukan pemahaman khusus dalam memahami kondisi dan situasi agar peserta didik dapat mengembangkan dirinya secara sempurna. Dengan demikian peneliti merasa penting untuk melakukan penelitian di Madrasah Aliyah Negeri 1 Banyuwangi terkait manajemen peserta didik sebagai upaya pencapaian prestasi peserta didik terutama dalam mencetak outputyang berkualitas.

2. Rumusan Masalah

1) Bagaimana penerapan manajemen peserta didik Madrasah Aliyah Negeri 1 Banyuwangi?

2) Bagaimana prestasi belajar peserta didik Madrasah Aliyah Negeri 1 Banyuwangi? 
3) Adakah pengaruh manajemen peserta didik terhadap prestasi belajar peserta didik Madrasah Aliyah Negeri 1 Banyuwangi?

4) Seberapa besar pengaruh manajemen peserta didik terhadap prestasi belajar peserta didik Madrasah Aliyah Negeri 1 Banyuwangi?

3. Tujuan Penelitian

1) Untuk mengetahui penerapan manajemen peserta didik Madrasah Aliyah Negeri 1 Banyuwangi.

2) Untuk mengetahui prestasi belajar peserta didik Madrasah Aliyah Negeri 1 Banyuwangi.

3) Untuk mngetahui pengaruh manajemen peserta didik terhadap prestasi belajar peserta didik Madrasah Aliyah Negeri 1 Banyuwangi.

4) Untuk mngetahui seberapa besar pengaruh manajemen peserta didik terhadap prestasi belajar peserta didik Madrasah Aliyah Negeri 1 Banyuwangi.

4. Manfaat Penelitian

1)Manfaat teoritis

a.Penelitian ini diharapkan dapat menambah khasanah pengetahun tentang manajemen pendidikan guna memberikan sumbangsih bagi prestasi peserta didik.

b. Penelitian ini juga di harapkan dapat menjadi masukan sekaligus referensi bagi peneliti selanjutnya yang relevan dengan tema penelitian ini.

2. Manfaat praktis

a. Menjadi masukan bagi kepala sekolah, guru, konselor, tenaga kependidikan, dan stakeholder pendidikan lainnya tentang penerapan manajemen peserta didik dalam upaya meningkatkan prestasi belajar peserta didik.

b. Memberikan konstribusi bagi pemimpin dan pengelola lembaga pendidikan islam pada objek yang diteliti, khususnya Madrasah Aliyah Negeri 1 Banyuwangi. 


\section{Landasan Teori}

1. Manajemen Peserta Didik

Menurut Nasihin dan Sururi (2009:205) mendefinisikan manajemen peserta didik ialah "layanan yang memusatkan perhatian pada pengaturan, pengawsan dan layanan siswa di kelas maupun di luar kelas”. Sedangkan menurut Hamalik (2010:93) manajemen peserta didik ialah "Proses pengurusan segala hal yang berkaitan dengan peserta didik, pembinaan sekolah mulai dari perencanaan penerimaan peserta didik, pembinaan selama peserta didik berada disekolah, sampai pada peserta didik melalui penciptaan suasana yang kondusif terhadap berlangsungnya proses belajar mengajar yang efektif dan efisien". Sedangkan menurut Prihatin (2014:4) mendefinisikan manajemen peserta didik ialah "Pekerjaan-pekerjaan atau kegiatan-kegiatan pencatatan peserta didik semenjak dari proses penerimaan sampai saat peserta didik meninggalkan sekolah karena sudah tamat mengikuti pendidikan pada sekolah itu. Dari pemaparan diatas dapat disimpulkan manajemen peserta didik adalah usaha pengaturan terhadap peserta didik mulai dari peserta didik mulai dari peserta didik tersebut masuk sekolah sampai mereka lulus sekolah.

Dari pengertian diatas dapat ditarik kesimpulan bahwa manajemen peserta didik adalah penataan dan pengaturan segala aktivitas yang berkaitan dengan peserta didik, yaitu dari mulai peserta didik masuk sekolah sampai peserta didik keluar dari sekolah.

2. Analisis kebutuhan peserta didik

Menurut Nasihin dan Sururi (2009:207) langkah pertama dalam kegiatan manajamen peserta didik adalah "melakukan analisis kebutuhan yaitu penempatan siswa yang dibutuhkan oleh lembaga pendidikan (sekolah)". Kegiatan yang dilakukan dalam langkah ini adalah:

a. Merencanakan jumlah peserta didik yang akan diterima

b. Menyusun program kegiatan kesiswaan.

3. Rekruitmen peserta didik

Menurut Nasihin dan Sururi (2009:208) rekruitmen peserta didik disebuah lembaga pendidikan pada hakikatnya merupakn proses pencarian, 
menentukan dan menarik pelamar yang mampu untuk menjadi peserta didik di lembaga pendidikan yang bersangkutan. Langkah-langkah rekruitmen peserta didik adalah sebagai berikut :

a. Pembentukan panitia penerimaan siswa baru.

b. Pembuatan dan pemasangan pengumuman penerimaan peserta didik baru yang dilakukan secara terbuka.

4. Seleksi peserta didik

Menurut Nasihin dan Sururi (2009 : 209) Seleksi peserta didik adalah "kegiatan pemilihan calon peserta didik untuk menentukan diterima atau tidaknya calon peserta didik menjadi peserta didik di lembaga pendidikan tersebut berdasarkan ketentuan yang berlaku". Seleksi peserta didik penting dilakukan terutama bagi lembaga pendidikan yang calon peserta didiknya melebihi dari daya tampung yang tersedia di lembaga pendidikan tersebut

Dari hasil seleksi terhadap peserta didik dihasilkan kebijakan sekolah yaitu: peserta didik yang diterima dan peserta didik yang tidak diterima. Bahkan bila diperlukan ada kebijakan peserta didik yang diterima tetapi sebagai cadangan. Setelah ditetapkan peserta yang diterima dan yang tidak diterima, kemudian diumumkan. Pengumuman hasil seleksi sebaiknya dilakukan sesuai dengan waktu yang telah ditentukan, supaya tidak menimbulkan keresahan bagi calon peserta didik. Pengumuman ini bisa dilakukan secara terbuka atau secara tertutup.

Bagi calon peserta didik yang diterima diharuskan mendaftar ulang pada lembaga pendidikan yang menerimanya. Pada waktu daftar ulang, biasanya calon peserta didik harus melengkapi pesyaratan-persyaratan administratif yang berguna bagi pengisian data peserta didik di lembaga pendidikan tersebut.

5. Orientasi

Orientasi peserta didik menurut Nasihin dan Sururi (2009:210) adalah, "kegiatan penerimaan siswa baru dengan mengenalkan situasi dan kondisi lembaga pendidikan tempat peserta didik itu menempuh pendidikan”. Situasi dan kondisi ini menyangkut lingkungan fisik sekolah dan lingkungan sosial sekolah. Lingkungan fisik sekolah seperti jalan menuju sekolah, 
halaman sekolah, tempat olah raga, gedung dan perlengkapan sekolah, serta fsilitas-fasilitas lainnya yang disediakan lembaga. sedangkan lingkungan sekolah meliputi kepala sekolah, guru-guru, tenaga TU, teman sebaya, kakakakak kelas, peraturan atau tata tertib sekolah, layanan-layanan sekolah bagi peserta didik serta kegiatan-kegiatan dan organisasi kesiswaan yang ada di lembaga.

6. Penempatan peserta didik (Pembagian kelas)

Sebelum peserta didik yang telah diterima pada sebuah lembaga pendidikan mengikuti proses pembelajaran, terlebih dahulu perlu ditempatkan dan dikelompokkan dalam kelompok belajarnya. Pengelompokkan peserta didik yang dilaksanakan pada sekolah-sekolah sebagian besar didasarkan kepada sistem kelas.

7. Pembinaan dan pengembangan peserta didik

Langkah berikutnya dalam manajemen peserta didik adalah melakukan pembinaan dan pengembangan terhadap peserta didik. Pembinaan dan pengembangan peserta didik dilakukan sehingga anak mendapatkan bermacam-macam pengalaman belajar untuk bekal kehidupannya dimasa yang akan datang. Untuk mendapatkan pengetahuan atau pengalaman belajar ini, peserta didik harus melaksanakan bermacam-macam kegiatan. Lembaga pendidikan (sekolah) dalam pembinaan dan pengembangan peserta didik biasanya melakukan kegiatan yang disebut` dengan kegiatan kurikuler dan kegiatan ekstra kurikuler.

Menurut Nasihin dan Sururi (2009 : 2012) kegiatan kurikuler adalah, "semua kegiatan yang telah ditentukan di dalam kurikulum yang pelaksanaannya dilakukan pada jam-jam pelajaran". Kegiatan kurikuler dalam bentuk proses belajar mengajar di kelas dengan nama mata pelajaran atau bidang studi yang ada di sekolah. Setiap peserta didik wajib mengikuti kegiatan kurikuler ini.

\section{Pencatatan dan pelaporan}

Pencatatan dan pelaporan tentang peserta didik di sebuah lembaga pendidikan (sekolah) sangat diperlukan. Menurut Prihatin (2014:76) kegiatan pencatatan dan pelaporan ini dimulai sejak peserta didik itu 
diterima di sekolah tersebut sampai mereka tamat atau meninggal sekolah tersebut. Pencatatan tentang kondisi peserta didik perlu dilakukan agar pihak lembaga dapat memberikan bimbingan yang optimal pada peserta didik. Sedangkan pelaporan dilakukan sebagai wujud tanggung jawab lembaga agar pihak-pihak terkait dapat mengetauhi perkembangan perkembangan peserta didik di diperlukan peralatan dan perlengkapan yang dapat mempermudah. Peralatan dan perlengkapan tersebut biasanya berupa: buku induk siswa, buku klapper, daftar prestasi, daftar mutasi peserta didik, buku catatan pribadi peserta didik, daftar nilai, buku lengger, buku raport.

9. Kelulusan dan alumni

Proses kelulusan merupakan kegiatan paling akhir dari manajemen peserta didik. Menurut Nasihin dan Sururi (2009: 214) Kelulusan adalah, "pernyataandari lembaga pendidikan tentang telah diselesaikannya program pendidikan yang harus diikuti oleh peserta didik". Setelah peserta didik selesai mengikuti seluruh program pendidikan di suatu lembaga pendidikan dan berhasil lulus dan ujian akhir, maka kepada peserta didik tersebut diberikan surat keterangan lulus atau sertifikat. Umumnya surat keterangan tersebut sering disebut Ijazah atau Surat Tanda Tamat Belajar (STTB).

Ketika peserta didik sudah lulus, maka secara formal hubungan antara peserta didik dan lembaga telah selesai. Namun demikian diharapkan hubungan antara alumni dan sekolah tetap terjalin. Dari hubungan sekolah dan alumni ini, lembaga pendidikan bisa memanfaatkan hasil-hasilnya. Lembaga pendidikan bisa menjaring berbagai informasi. Misalnya informasi tentang materi pelajaran mana yang sangat membantu untuk studi selanjutnya. Mungkin juga informasi tentang lapangan kerja yang bisa dijangkau bagi alumni lainnya.

Hubungan antara sekolah dengan para alumni dapat dipelihara lewat pertemuan-pertemuan yang diselenggarakan oleh para alumni, yang bisa disebut "reuni". Nasihin dan Sururi (2009:211) menjelaskan bahwa saat ini disetiap lembaga pendidikan ada organisasi alumninya, misalnya IKA (Ikatan Alumni), prestasi yang dicapai para alumni dari lembaga pendidikan ini perlu didata atau dicatat oleh lembaga. Sebab catatan tersebut 
sangat berguna bagi lembaga dalam mempromosikan lembaga pendidikannya.

10. Prestasi Belajar

a. Definisi Prestasi Belajar

Pengertian prestasi belajar dalam (KBBI) Kamus Besar Bahasa Indonesia (2013:103) ialah, "penguasaan pengetahuan atau keterampilan yang dikembangkan oleh mata pelajaran, lazimnya ditunjukkan dengan nilai tes atau angka nilai yang diberikan oleh guru". Dalam hal ini prestasi belajar merupakan suatu kemajuan dalam perkembangan peserta didik setelah ia mengikuti kegiatan belajar dalam waktu tertentu. Seluruh pengetahuan, keterampilan, kecakapan dan prilaku individu terbentuk dan berkembang melalui proses belajar.

Sedangkan menurut sudjana (2008:19) bahwa prestasi belajar didalamnya mencakup tiga aspek yaitu: aspek kognitif (penguasaan intelektual), aspek afektif (berhubungan dengan sikap dan nilai), serta aspek psikomotorik (kemampuan keterampilan bertindak dan bertingkah laku). Ketiganya tidak berdiri sendiri tetapi merupakan satu kesatuan yang tidak terpisahkan, bahkan membentuk hubungan hirarki. Sedangkan harahap dalam dalam sukardi mengemukakan bahwa prestasi balajar ialah, "penilaian pendidikan tentang perkembangan dan kemajuan murid yang berkenan dengan penguasaan bahan pelajaran yang di sajikan kepada mereka serta nilai-nilai yang terdapat dalam kurikulum".

b. Faktor-faktor yang Mempengaruhi Prestasi Belajar

Nana Sudjana (2011:59) mengemukakan bahwa faktor-faktor yang mempengaruhi prestasi belajar siswa dapat dibedakan menjadi tiga macam, yaitu:

a) Faktor Jasmani

b) Faktor Psikologis

c) Faktor Kelelahan

c. Pengukuran Prestasi Belajar

Penyusunan alat ukur dilakukan dengan data yang telah diperoleh, dan dari evaluasi dalam bentuk ujian, yang menyerupai tes untuk 
mengetahui apakah pelajaran yang disajikan itu berhasil dipelajari oleh siswa atau tidak. Dalam dunia pendidikan, menilai merupakan salah satu kegiatan yang tidak dapat ditinggalkan. Menilai merupakan salah satu proses belajar dan mengajar. Di Indonesia, kegiatan menilai prestasi belajar bidang akademik di sekolah-sekolah dicatat dalam sebuah buku laporan. Dalam rapor dapat diketahui sejauhmana prestasi belajar seorang peserta didik, apakah peserta didik tersebut berhasil atau gagal dalam suatu mata pelajaran. Sumadi Suryabrata (2010 : 76) mengemukakan bahwa rapor merupakan perumusan terakhir yang diberikan oleh guru mengenai kemajuan atau hasil belajar peserta didiknya selama masa tertentu.

Syaifuddin Azwar (2010 : 296) menyebutkan bahwa ada beberapa fungsi penilaian dalam pendidikan, yaitu:

1) Penilaian berfungsi selektif (fungsi sumatif)

2) Penilaian berfungsi diagnostik

\section{B. Metode Penelitian}

1. Jenis penelitian ini deskriptif kuantitatif.

2. Populasi yang digunakan dalam penelitian ini bersifat penalitian populasi karena jumlah subjek kurang dari 100.

3. Teknik pengumpulan data yang digunakan adalah kuesioner, observasi dan dokumentasi.

4. Validitas data menggunakan rumus uji korelasi product moment.

5. Reliabilitas data menggunakan rumus Alpha.

6. Analisis data menggunakan analisis kualitatif untuk menjawab rumusan masalah nomor 1 dan 2 dan analisis kuantitatif untuk menjawab rumusan masalah nomor 3 dengan menggunakan rumus regresi linier sederhana. 


\section{Hasil Penelitian}

1. Uji Validitas

Uji validitas merupakan cara untuk menguji apakah instrumen yang digunakan dapat mengukur apa yang seharusnya diukur atau tidak. Dalam hal ini uji validitas dilakukan dengan pengujian t-test, yaitu dengan membandingkan antara $t$ hitung dan t tabel. Apabila t hitung lebih besar dari t tabel, maka perbedaan yang ada adalah signifikan, sehingga instrumen bisa dinyatakan valid. Tingkat signifikansinpada uji $\mathrm{t}$ adalah 0,05 atau $5 \%$. Hasil uji validitas terhadap instrumen penelitian ini disajikan pada tabel berikut:

Tabel 1

Hasil Uji Validitas Data Variabel X

\begin{tabular}{|c|c|c|c|c|}
\hline No & $\begin{array}{c}\text { Item } \\
\text { Pertanyaan }\end{array}$ & Corrected Item- & $\begin{array}{c}\text { r tabel } \\
\mathbf{5 \%})\end{array}$ & Kriteria \\
\hline 1 & X1 & 0,517 & 0,344 & Valid \\
\hline 2 & X2 & 0,753 & 0,344 & Valid \\
\hline 3 & X3 & 0,760 & 0,344 & Valid \\
\hline 4 & X4 & 0,525 & 0,344 & Valid \\
\hline 5 & X5 & 0,502 & 0,344 & Valid \\
\hline 6 & X6 & 0,436 & 0,344 & Valid \\
\hline 7 & X7 & 0,587 & 0,344 & Valid \\
\hline 8 & X8 & 0,738 & 0,344 & Valid \\
\hline 9 & X9 & 0,745 & 0,344 & Valid \\
\hline 10 & X10 & 0,645 & 0,344 & Valid \\
\hline 11 & X11 & 0,621 & 0,344 & Valid \\
\hline 12 & X12 & 0,608 & 0,344 & Valid \\
\hline 13 & X13 & 0,756 & 0,344 & Valid \\
\hline
\end{tabular}

Tabel 2

Hasil Uji Validitas Data Variabel Y

\begin{tabular}{|c|c|c|c|c|}
\hline No & Item Pertanyaan & $\begin{array}{c}\text { Corrected Item- } \\
\text { Total Correlation }\end{array}$ & $\begin{array}{c}\mathbf{r} \text { tabel } \\
\mathbf{( 5 \% )}\end{array}$ & Kriteria \\
\hline 1 & Y1 & 0,447 & 0,344 & Valid \\
\hline 2 & Y2 & 0,602 & 0,344 & Valid \\
\hline 3 & Y3 & 0,608 & 0,344 & Valid \\
\hline 4 & Y4 & 0,367 & 0,344 & Valid \\
\hline 5 & Y5 & 0,352 & 0,344 & Valid \\
\hline
\end{tabular}

Pengaruh Manajemen Peserta Didik Terhadap Prestasi Belajar Peserta Didik Madrasah Aliyah Negeri 1 Banyuwangi

Mamlukhah, Amirotun Nahdliyah, Hanim Wafiroh 


\begin{tabular}{|c|c|c|c|c|}
6 & Y6 & 0,577 & 0,344 & Valid \\
\hline 7 & Y7 & 0,528 & 0,344 & Valid \\
\hline 8 & Y8 & 0,710 & 0,344 & Valid \\
\hline 9 & Y9 & 0,462 & 0,344 & Valid \\
\hline 10 & Y10 & 0,481 & 0,344 & Valid \\
\hline 11 & Y11 & 0,471 & 0,344 & Valid \\
\hline 12 & Y12 & 0,500 & 0,344 & Valid \\
\hline 13 & Y13 & 0,588 & 0,344 & Valid \\
\hline
\end{tabular}

Sumber : Hasil Olahan Peneliti 2019

Berdasarkan data pada tebel di atas, diketahui bahwa semua pengujian terhadap instrumen variabel $\mathrm{X}$ maupun variabel $\mathrm{Y}$, menunjukkan bahwa seluruh pertanyaan yang diajukan adalah valid. Nilai $r$ tabel untuk tingkat signifikan 0,05 dan jumlah item 33-2 = 31 adalah 0,344. Dengan demikian semua butir pertanyaan dalam kuesioner tersebut dapat dipercaya dan dapat digunakan untuk mengumpulkan data yang diperlukan.

\section{Uji Reabilitas}

Sebuah instrumen dapat dikatakan reliabel apabila ketika instrumen tersebut digunakan untuk mengukur gejala atau obyek yang sama lebih dari satu kali akan diperoleh hasil pengukuran yang sama. Pengujian reliabilitas dilakukan dengan menggunakan teknik Cronbach Alpha. Suatu data dikatakan reliabel apabila memenuhi persyaratan nilai Cronbach alpha > 0,6. Hasil uji reliabilitas terhadap data penelitian disajikan pada tabel berikut ini

Tabel 3

Hasil Uji Reliabilitas Data

\begin{tabular}{|c|c|c|c|}
\hline NO & Variabel & Cronbach Alpha & Kriteria \\
\hline 1 & Manajemen Peserta Didik & 0,874 & Kuat \\
\hline 2 & Prestasi Belajar & 0,709 & Kuat \\
\hline
\end{tabular}

Sumber : Olahan Peneliti 2019

Hasil analisis pada tabel di atas menunjukkan bahwa nilai Cronbach alpha dari masing-masing variabel ada pada kriteria kuat. 
Dengan demikian dapat disimpulkan bahwa semua alat ukur yang digunakan dalam penelitian ini adalah reliabel.

3. Uji Normalitas Data

Uji normalitas merupakan cara untuk menguji apakah variabel variabel dalam sebuah model regresi mempunyai distribusi normal atau tidak. Pengujian dilakukan dengan menggunakan SPSS 16 untuk menganalisis data tersebut, Adapun hasil analisisnya, peneliti sajikan dalam gambar dibawah ini:

\section{Normal P-P Plot of Regression Standardized Residual}

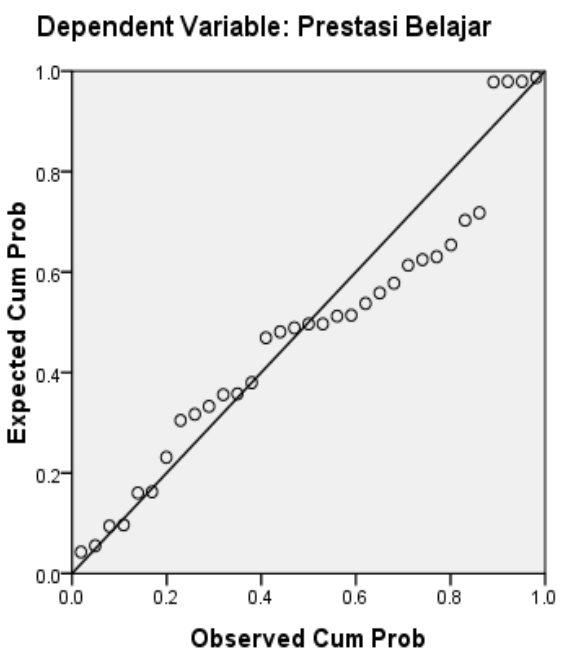

Gambar 1 Normal P-P Plot of Regression Standardized Residual

Sumber: Output SPSS data viewer 2019

Dari plot diatas dapat disimpulkan bahwa:

1. Variabel-Variabel tersebut mempunyai hubungan yang cukup dekat, karena titik-titik pada diagram pencar itu terletak mendekat pada garis.

2. Variabel-variabel tersebut mempunyai hubungan positif karena titik pada diagram pencar menunjukkan gejala dari bawah ke kanan atas. 
3. Variabel-variabel tersebut mempunyai korelasi yang linier, kerena titik pada diagram pencar menunjukkan gejala garis lurus.

4. Sebaran data ada disekitar garis diagonal sehingga dapat diambil kesimpulan bahwa data berdistribusi normal.

4. Pengujian Hipotesis

Analisis regresi memerlukan pengujian sesuai untuk memastikan keeratan hubungan dari variabel-variabel yang digunakan. Pengujian tersebut meliputi uji $\mathrm{F}$ dan $\mathrm{T}$.

1) Uji T

Uji T digunakan untuk mengetahui apakah pengaruh variabel manajemen peserta didik (X) dan variabel prestsi peserta didik (Y) signifikan atau tidak. Kesimpulan dari uji $\mathrm{T}$ diperoleh setelah membandingkan $\mathrm{t}$ hitung dan $\mathrm{t}$ tabel dengan taraf signifikansi $5 \%$ atau $1 \%$ kriteria pengambilan keputusannya adalah:

a) Apabila $\mathrm{t}$ hitung $>\mathrm{t}$ tabel, maka Ho ditolak dan Ha diterima, yang artinya variabel bebas secara parsial memiliki pengaruh nyata dan signifikan terhadap variabel terkait.

b) Apabila t hitung < t tabel, maka Ho diterima dan Ha di tolak, yang artinya variabel bebas secara parsial tidak memiliki pengaruh nyata dan tidak signifikan terhadap variabel terkait.

Hasil analisis uji t dalam penelitian ini disajikan dalam tabel berikut:

Tabel 4

Hasil Uji t

Coefficients $^{\mathrm{a}}$

\begin{tabular}{|c|c|c|c|c|c|}
\hline \multirow[b]{2}{*}{ Model } & \multicolumn{2}{|c|}{ Unstandardized Coefficients } & \multirow{2}{*}{$\begin{array}{c}\begin{array}{c}\text { Standardized } \\
\text { Coefficients }\end{array} \\
\text { Beta }\end{array}$} & \multirow[b]{2}{*}{$\mathrm{T}$} & \multirow[b]{2}{*}{ Sig. } \\
\hline & B & Std. Error & & & \\
\hline (Constant) & 5.098 & 3.690 & & 1.382 & .180 \\
\hline Manajemen Peserta Didik & .937 & .043 & .977 & 21.883 & .000 \\
\hline
\end{tabular}


Coefficients $^{\mathrm{a}}$

\begin{tabular}{|c|c|c|c|c|c|}
\hline \multirow[b]{2}{*}{ Model } & \multicolumn{2}{|c|}{ |Unstandardized Coefficients } & \multirow{2}{*}{$\begin{array}{c}\text { Standardized } \\
\text { Coefficients }\end{array}$} & \multirow[b]{2}{*}{$\mathrm{T}$} & \multirow[b]{2}{*}{ Sig. } \\
\hline & B & Std. Error & & & \\
\hline (Constant) & 5.098 & 3.690 & & 1.382 & .180 \\
\hline Manajemen Peserta Didik & .937 & .043 & .977 & 21.883 & .000 \\
\hline
\end{tabular}

a. Dependent Variable: Prestasi Belajar

Hasil : Olahan peneliti 2019

Berdasarkan tabel analisis uji $\mathrm{t}$ tersebut dapat ditarik kesimpulan bahwa variabel perencanaan implementasi kurikulum (X) t hitung yaitu 21.883 dibandingkan dengan $\mathrm{N}=$ 33-2 taraf signifikansi $5 \%=2,042$ dan $\mathrm{t}$ tabel dengan $\mathrm{N}=33-$ 2 taraf signifikansi $1 \%=2,750$, menghasilkan hasil uji $t$ hitung > t tabel, maka Ha diterima. Sedangkan uji $\mathrm{t}$ yang diperoleh dari hasil hitung variabel efektivitas pembelajaran (Y) sebesar 1,382 dibandingkan $\mathrm{t}$ tabel dengan $\mathrm{N}=33-2$ taraf signifikansi $5 \%=2,042$ dan $\mathrm{t}$ tabel dengan $\mathrm{N}=33-2$ taraf signifikansi $1 \%=2,750$ didapatkan hasil uji $\mathrm{t}$ hitung $>\mathrm{t}$ tabel, maka Ha diterima. Dari penjelasan diatas menyatakan bahwa variabel manajemen peserta didik (X) mempunyai pengaruh yang signifikan terhadap prestasi belajar (Y).

2) Uji F

Uji $F$ atau uji koefisien regresi secara serentak digunakan untuk mengetahui apakah variabel manajemen peserta didik (X) dan variabel prestasi belajar peserta didik (Y) secara signifikan atau tidak. Kesimpulan dari uji F ini diperoleh dengan cara membandingkan antara $\mathrm{F}$ hitung dan $\mathrm{F}$ tabel dengan taraf signifikansi $5 \%$ dan $1 \%$. Kriteria pengambilan keputusannya adalah:

1. Apabila $\mathrm{F}$ hitung $>\mathrm{F}$ tabel, maka Ho ditolak dan Ha diterima, yang artinya variabel bebas secara simultan memiliki pengaruh yang signifikan terhadap variabel terkait. 
2. Apabila $\mathrm{F}$ hitung $>\mathrm{F}$ tabel, maka Ho diterima dan Ha ditolak, yang artinya variabel bebas secara simultan tidak memiliki pengaruh yang signifikan terhadap variabel terkait.

Hasil analisis uji $\mathrm{F}$ dalam penelitian ini disajikan dalam tabel berikut ini:

Tabel 5

Hasil Uji F

ANOVA $^{\mathrm{D}}$

\begin{tabular}{|c|c|c|c|c|c|c|}
\hline & Model & Sum of Squares & Df & Mean Square & $\mathrm{F}$ & Sig. \\
\hline \multirow[t]{3}{*}{1} & Regression & 2907.014 & 1 & 2907.014 & 478.860 & $.000^{\mathrm{a}}$ \\
\hline & Residual & 139.626 & 31 & 6.071 & & \\
\hline & Total & 3046.640 & 32 & & & \\
\hline
\end{tabular}

a. Predictors: (Constant), Manajemen Peserta Didik

b. Dependent Variable: Prestasi Belajar

\section{Hasil : olahan peneliti 2019}

Berdasarkan hasil yang tersaji pada tabel tersebut diatas diketahui bahwa F hitung yaitu , 478.860 dibandingkan $\mathrm{t}$ tabel dengan $\mathrm{N}=33-2$ taraf signifikansi $5 \%=2,50$ dan $\mathrm{t}$ tabel dengan $\mathrm{N}=33-2$ taraf signifikansi $1 \%=4,14$ menghasilkan hasil uji $\mathrm{F}$ hitung $>\mathrm{F}$ tabel, maka Ha diterima, yang berarti variabel bebas, yaitu manajemen peserta didik (X) secara simultan atau bersama-sama memiliki pengaruh signifikan terhadap variabel terikat prestasi belajar peserta $\operatorname{didik}(\mathrm{Y})$

\section{Pembahasan}

\section{a. Pengaruh Manajemen Peserta Didik (X)}

Sesuai dengan apa yang diuraikan pada bagian sebelumnya bahwa permasalahn pertama yang dipertanyakan dalam penelitian ini adalah bagaimana penerapan manajemen peserta didik terhadap prestasi belajar peserta didik Madrasah Aliyah Negeri 1 Banyuwangi Tahun Pembelajaran 2018/2019. Maka hasil penelitian ini menunjukkan 
bahwa tingkat prosentase variabel $\mathrm{X}$ yang berhasil dicapai sebesar $77,5 \%$.

Berdasarkan data di atas, tingkat prosentase variabel $\mathrm{X}$ yang berhasil dicapai adalah sebesar 77,5\%. Jika dilihat pada tabel indeks konfirmasi nialai angket, maka nilai tersebut berada pada interval $61 \%$ sampai dengan $80 \%$ dengan kategori kuat. Hal ini menunjukkan bahwa pengaruh manajemen peserta didik terhadap prestasi belajar peserta didik Madrasah Aliyah Negeri 1 Banyuwangi Tahun Pembelajaran 2018/2019 tergolong kuat.

b. Prestasi Peserta Didik (Y)

Sesuai dengan apa yang diuraikan pada bagian sebelumnya bahwa permasalahan kedua yang dipertanyakan dalam penelitian ini adalah bagaimana prestasi belajar peserta didik Madrasah Aliyah Negeri 1 Banyuwangi tahun pembelajaran 2018/2019. hasil penelitian ini menunjukkan bahwa tingkat prosentase variabel $\mathrm{Y}$ yang berhasil dicapai $81,3 \%$

Berdasarkan data di atas, tingkat prosentase variabel $\mathrm{X}$ yang berhasil dicapai adalah sebesar $81,3 \%$. Jika dilihat pada tabel indeks konfirmasi nilai angket, maka nilai tersebut berada pada interval $81 \%$ sampai dengan $100 \%$ dengan kategori sangat kuat. Hal ini menunjukkan bahwa Prestasi Peserta didik Madrasah Aliayah Negerei 1 Banyuwangi tergolong sangat kuat.

c. Pengaruh Manajemen Peserta Didik (X) Terhadap Prestasi Belajar Peserta Didik (Y)

Permasalahan ketiga yang ingin dijawab dalam penelitian ini adalah pengaruh manajemen peserta didik (X) terhadap prestasi belajar peserta didik (Y). Berdasarkan hasil uji $\mathrm{F}$ hitung yaitu, 60,756 dibandingkan $\mathrm{t}$ tabel dengan $\mathrm{N}=33$ taraf signifikansi 5\% $=2,50$ dan $\mathrm{t}$ tabel dengan $\mathrm{N}=33$ taraf sigmifikansi $1 \%=4,14$ menghasilkan uji f hitung > f tabel, maka Ha diterima, yang berarti variabel bebas, yaitu pengaruh manajemen peserta didik (X) secara simultan atau bersama-sama memiliki pengaruh signifikan terhadap 
variabel terikat prestasi belajar peserta didik Madrasah Aliyah Negeri 1 Banyuwangi (Y).

d. Besar Pengaruh Manajemen Peserta Didik (X) Terhadap Prestasi Belajar Peserta Didik (Y)

Permasalahan keempat yang ingin dijawab dalam penelitian ini adalah seberapa besar pengaruh variabel manajemen peserta didik (X) terhadap prestasi belajar peserta didik (Y). Hasil penelitian menunjukkan bahwa pengaruh manajemen peserta didik mempunyai pengaruh terhadap prestasi belajar peserta didik sebesar 95,4\% dan sisanya $4,6 \%$ dipengaruhi oleh variabel lain.

\section{E. Kesimpulan}

Berdasarkan hasil penelitian dan analisis data sebagaimana diuraikan pada bab sebelumnya dapat disimpulkan sebagai berikut :

1. Berdasarkan hasil angket variabel $X$ manajemen peserta didik diperoleh hasil hitung sebesar 77,5\% yang termasuk kategori kuat.

2. Berdasarkan hasil angket variabel prestasi belajar peserta didik Madrasah Aliyah Negeri 1 Banyuwangi memperoleh hasil sebesar 81,3\% tergolong sangat kuat.

3. Berdasarkan hasil uji $\mathrm{f}$ yang menghasilkan bahwa $\mathrm{f}$ hitung yaitu, 478.860 dibandingkan $\mathrm{t}$ tabel dengan $\mathrm{N}=33$ taraf signifikan $5 \%=$ 0,344 dan $\mathrm{t}$ tabel dengan $\mathrm{N}=33$ taraf signifikansi $1 \%=0,442$ menghasilkan uji f hitung > ftabel, maka Ha diterima, yang berarti variabel bebas, yaitu manajemen peserta didik (X) secara simultan atau bersama-sama memiliki pengaruh signifikan terhadap variabel prestasi belajar peserta didik Madrasah Aliyah Negeri 1 Banyuwangi (Y).

4. Berdasarkan hasil analisis regresi diketahui bahwa nilai $\mathrm{R}$ atau koefisien korelasi sebesar 0,977, sedangkan nilai $\mathrm{R}$ Sguare hasil pengkuadrata nilai $\mathrm{R}$ atau $\mathrm{R}$ koefisien determinasi (KD) sebesar 0,954, yang dapat diartikan bahwa variabel bebas (X) memiliki pengaruh kontribusi sebesar 95,4\% terhadap variabel terikat (Y) dan $4,6 \%$ dipengaruhi oleh faktor-faktor lain di luar variabel X. Dengan 
demikian ada pengaruh perencanaan imlementasi kurikulum terhadap prestasi belajar peserta didik Madrasah Aliyah Negeri 1 Banyuwangi sebesar $95,4 \%$ sedangkan sisanya $4,6 \%$ dipengaruhi oleh variabel lain.

\section{F. Daftar Pustaka}

Danim, Sudarwan. 2010. Pengantar Kependidikan. Bandung : Alfabeta

Hamalik, Oemar. 2009. Proses Belajar Mengajar. Jakarta. PT Bumi Aksara

Hermino, Agustinus. 2016. Manajemen Kemarahan Siswa.Yogyakarta : Pustaka Pelajar

Hidayat, Wijaya. 2017. Ayat-Ayat Al Quran Tentang Manajemen Pendidikan Islam. Medan. LPPI

Imron, Ali. 2012. Manajemen Peserta Didik Berbasis Sekolah. Jakarta : PT Bumi Aksara

Juni, Priansa, Donni. 2015. Manajemen Peserta Didik dan Model Pembelajaran. Bandung : Alfabeta

Marbun, Stefanus, 2018. Psikologi Pendidikan. Ponorogo. Uwais Inspirasi Indonesia

Maunah, Binti. 2009. Landasan Pendidikan. Yogyakarta : Teras

Muslim, Bukhori. Shohih Muslim. Semarang. Karya Toha Putra

Nasihin, Sukarti. 2009. Manajemen Pendidikan. Bandung : Alfabeta

Nasihin, Sururi. 2009. Manajemen Pendidikan. Bandung : Alfabeta

Sukardi. 2009. Evaluasi Pendidikan Prinsip dan Oprasionalnya. Jakarta : PT Bumi Aksara

Yamin, Martinis dan Maisah. 2009. Manajemen Pembelajaran Kelas. Jakarta : GP Press 